\title{
Testing the Effects of Employee Empowerment, Teamwork, and Employee Training on Employee Productivity in Higher Education Sector
}

\author{
Jalal Hanaysha \\ Senior Lecturer, Faculty of Business and Management \\ DRB-HICOM University of Automotive Malaysia, 26607, Pekan, Pahang, Malaysia \\ E-mail: jalal.hanayshi@yahoo.com
}

Received: March 23, 2016 Accepted: March 24, 2016 Published: April 26, 2016

Doi:10.5296/ ijld.v6i1.9200ＵRL: http://dx.doi.org/10.5296/ ijld.v6i1.9200

\begin{abstract}
Improving employee productivity is one of the most important objectives for any organization. This is because highly productive employees can influence overall organizational performance. This study aims to test the direct effects of employee empowerment, teamwork, and employee training on employee productivity in higher education sector. Based on the review of past literature, it is clear that only few studies were conducted on employee productivity, particularly, in education sector. Therefore, the data of this study were collected using an online survey from a sample of 242 employees serving at public universities in northern Malaysia. To analyse the collected data, SPSS and structural equation modelling were utilized. The results revealed that employee empowerment has significant positive effect on employee productivity. It was also found that teamwork has significant positive effect on employee productivity. Finally, the study found that employee training has significant positive effect on employee productivity. These findings provide useful implications for policy makers to set out their strategies with regard to human resource factors to in order to enhance both employee productivity and organizational performance.
\end{abstract}

Keywords: Employee empowerment, employee productivity, employee training, teamwork.

\section{Introduction}

Improving employee productivity has been a central issue in past research both in manufacturing as well as in service sectors. This is because increased employee productivity can affect the overall performance of an organization and its competitive advantage. Kien (2012) declared that productivity is an important factor for building organizational competitiveness, sustaining its strategic and financial performance, attaining the desired goal, 
and meeting the value propositions of its stakeholders. Vrat, Sardana and Sahay (2009) demonstrated that the efforts to maximize productivity come from the effective management. The term productivity was described in the literature as a measure of the amount of output that is obtained from an employee over a period of time (Mokhtar, Nooreha, Nik Mustapha, and Mazilan, 2003; Käpylä, Jääskeläinen, and Lönnqvist, 2010). Moreover, productivity reflects the use of different resources or inputs in an organization to attain planned or favourable outcomes. In general, productivity refers to the output that an employee achieves over a specific period of time.

An efficient and effective utilization of human resources in an organization is very important to improve its overall effectiveness and efficiency. Past literature reveals that employee productivity can be influenced by various organization behavioural factors such as employee training (Bhat, 2013), employee empowerment, and teamwork. Training is an ongoing process through which employees truly obtain the necessary knowledge and be able to know how to perform well in an organization. An organization that is capable to design an environment which emphasizes on training that can be valued by its employees will have better chances to obtain greater commitment (Hanif and Abdullah, 2013). Similarly, employee empowerment is a significant strategy that many organizations use to improve the strengths and involvement of their employees assuming that empowered employee are likely to be more efficient in their job duties (Saifullah, Alam, Zafar, and Humayon, 2015). Benrazavi and Silong (2013) also considered teamwork as an important factor that contributes to employee performance. Teamwork is a mutual activity that aims to achieve a common goal through involving organizational members in certain groups to share their knowledge and skills with each other.

Enhancing employee productivity is one of the main concerns for the management in any organization. However, despite the importance of this topic, it is evident in the literature that the theoretical and empirical research on employee productivity is scarce. Moreover, it is noted there are limited studies which examined the effects of employee training, employee empowerment, and teamwork on employee productivity in Asian context. Therefore, this study aims to provide significant contributions to the body of knowledge and empirical research on this topic by examining the effects of the stated factors on employee productivity in Malaysian higher education sector. The education industry was selected to conduct this study due to the lack of empirical research on employee productivity in this context. Moreover, higher educational institutions in the country are competitive and therefore, it is important to examine the effects of behavioural factors that determine employee productivity and commitment which resultantly could lead to greater effectiveness. The next sections start by literature review, methodology, analysis of results, and then discussion and conclusion follow.

\section{Literature Review}

\subsection{Employee Productivity}

The issue of employee productivity has recently emerged in the literature as one of the foremost critical challenges for organizations to manage their workforce. As much of an 
organizational success depends on the productivity of its employees, thus, productivity is a very important consideration for various businesses. In other words, the productivity of employees is a vital theme that should be given greater attention, because the main purpose of doing the work is to gain the maximum output with minimum costs. Sultana, Irum, Ahmed, and Mehmood (2012) described productivity as the ability to achieve certain tasks according to predetermined or specified accuracy standards, completeness, cost, and speed. That is, employee productivity can be assessed in terms of the efficiency of an employee in doing his or her tasks. Overall, employee productivity can be evaluated in terms of the output of an employee over a specific period of time.

A number of definitions for employee productivity were proposed by various scholars. For instance, Ferreira and Du Plessis (2009) described it as the time spent by an employee in executing his or her job duties, in order to achieve expected outcomes based on the job description. Moreover, Mathis and Jackson (2000) demonstrated that employee productivity can be assessed based on the quantity and quality of work done by an employee taking into consideration the costs of resources being used to achieve that work. Kien (2012) indicated that increasing employee's productivity can lead to favourable outcomes such as: competitive advantage, maintaining strategic and financial results, achieving organizational goals, and fulfilling stakeholders' value propositions. The author concluded that looking for the important factors that may influence employee productivity is vital to enhance organizational efficiency. Therefore, human resource managers should be able to design human resource programs that can drive organizational productivity.

Kawara (2014) asserted that one of the common approaches to increase employee productivity includes linking rewards to the amount and quality of performance via different types of incentives. Moreover, training has been regarded as a key factor for developing organizational productivity. Certain of scholars (Colombo and Stanca, 2008; Sepulveda, 2010) considered training as an essential and effective tool in the successful achievement of organizational goals and objectives, resulting in higher productivity. The increase in employee productivity is also assumed to come from better workplace environment (Hameed, and Amjad, 2009) as the physical layout of offices can motivates employees and eventually increase their productivity. Moreover, Brown (2012) suggested that employee productivity can be maximized when there is a reasonable balance, thus, employees would have adequate control, authority, and feel empowered to make the most effective decisions. Conversely, Michac (1997) identified several reasons for being less productive as follows; ineffective training in the organization, absence of written performance standards, poor planning and motivation, frequent change, undesirable atmosphere and work environment, insufficient communication at various levels, and non-description with organizational goals.

\subsection{Employee Empowerment}

Organizations of all types should provide their employees with the possible opportunities to improve their talents and knowledge in order to achieve long-term goals and ensure mutual benefits. A key feature of a successful team appears in the investment with significant level of empowerment and authority of decision making. According to Jacquiline (2014), 
organizations that are performance oriented should focus on employee empowerment and job satisfaction in their decision making in order to achieve such desired goal. Employee empowerment is one of the valued concepts that are considered to be important in improving the behavioural elements of employees to achieve higher degree of support, innovation, teamwork spirit, entrepreneurship, self-confidence, and independent thinking (Elnaga and Imran, 2014). Employee empowerment was previously defined as endowing the power to an employee to make decisions when needed (Hunjra, UlHaq, Akbar, and Yousaf, 2011). Moreover, Daft (2001) described empowerment as offering employee the freedom, control, and opportunities to involve in decision-making and organizational matters.

In the current era which is marked by high globalization, there is need for organizations to focus on empowerment to enable the qualified employees to make necessary decisions and respond to any changes that may arise in the business environment at any time. Employee empowerment is built by designing a working environment where employees are allowed to make their own decisions based on certain work-related conditions (Elnag and Imran, 2014). According to Wadhwa and Verghese (2015), empowerment is a process of transferring power, authority with responsibility, and accountability to employees through their managers. As result, empowered employee will usually develop competency to actively perform their tasks by applying their knowledge and skills (Jacquiline, 2014). The advantages of employee empowerment include increased responsibility, high employee morale, and better quality of work life. Meyerson and Dewettinck (2012) regarded employee empowerment as a motivational tool that aims to increase organizational performance if managed properly by increasing the participation and self-determinations of employees.

Employee empowerment has widely been recognized as a key contributor to organizational success, and many authors observed a direct relationship between the levels of employee empowerment and employee performance. Dobbs (1993) stated that empowerment affects the performance of employees and also creates a favourable work environment. According to Ripley and Ripley (1992), empowerment leads to positive organizational outcomes, such as enhanced employees' responsibilities and motivation in the routine work, improved level of job satisfaction, better quality of services, higher employee's loyalty, low turnover intention, and maximized productivity. By adopting the empowerment strategy, it is believed that employees would feel the self-respect which is worthy for them, and it can ultimately increases their productivity and quality of work. Meyerson and Dewettinck (2012) also found that empowerment had a significant positive effect on employee productivity. Based on the above discussion, the following hypothesis is proposed:

H1: Employee empowerment has positive effect on employee productivity.

\subsection{Teamwork}

Nowadays, many organizational divisions have adopted the culture of teamwork as key to achieve greater success. Teamwork was previously viewed as the actions of employees brought together to attain a certain objective or goal by placing the interests of each member to the interest of the overall group (Chukwudi, 2014). Similarly, Ooko (2013) thought about teamwork as a group of people working together in order to attain a common goal. The 
author indicated that teams in organizations usually consist of employees who acquire necessary skills that are important to achieve the desired objectives. In this incident, all team members have the opportunities to teach each other how to perform a particular task skilfully and professionally. Hence, the greater the degree of collaboration among team members, the higher is the opportunity for shared learning and the greater is the level of productivity. Besides that, working in a team allows employees to feel empowered and this supports them to develop autonomy, which is a source of job satisfaction and low stress levels (Oso, 2002).

In the current business markets where competition is high, organizations' managers recognize the significance of teamwork, because working in teams can enlarge the outputs of employee through collective collaboration. Additionally, teamwork is becoming the key strategy to staff development in several organizations. According to Alie, Beam and Carey (1998), teamwork can be the smartest growth strategy, and usually employees who work in teams are likely to become the key assets for the organization. This is because teamwork is the tool for improving the utilization of employee-power that can ultimately increase his or her performance. Manzoor, Ullah, Hussain and Ahmad (2011) revealed that the support of top level management can help an employee to confidently work with others in groups, and this as a result can increases his/ her productivity. Certain scholars added that teamwork enables people to help each together, improves their individual skills, and obtain positive feedback without any conflict between them (Jones, Richard, Paul, Sloane, and Peter, 2007). Consequently, team members who get the opportunities to learn and apply new skills will have more favourable attitudes towards teamwork (Jiang, 2010).

Previous literature reported that teamwork is the key result of successful managements aiming to improve overall organizational outcomes in terms of productivity. Mbinya (2013) demonstrated that the majority of organizations focus on teamwork in an attempt to achieve their targets. Past studies found that teamwork has significant positive effect on employee productivity and organizational performance. That is, organizations which emphasize more on teams can enjoy favourable outcomes such as enlarged employee performance, higher productivity and better skills in problem solving (Cohen and Bailey, 1999). Moreover, Gallie, Zhou, Felstead and Green (2009) confirmed that teamwork enriches performance through the increased scope of using employees' knowledge, skills, and abilities and sharing them with other members. The authors added that teamwork enhances employee productivity and it leads to favourable levels of commitment toward the organisation. Based on the above discussion, the following hypothesis is presented:

H2: Teamwork has positive effect on employee productivity.

\subsection{Employee Training}

To manage human resources in any organization, training is one of the essential activities. The key principles of training focus on the needs of employees to do meaningful work through learning programs supported by scientific theories taking into account the elements of efficiency, effectiveness, and individual differences (Diab and Ajlouni, 2015). Organizations can develop and increase the quality of their employees by providing inclusive training and development programs (Singh and Mohanty, 2012). Training is an organizational 
activity that is systematically planned and results in an improved level of skill, knowledge and competency that are necessary to ensure effective performance (Betcherman, 1992). In other words, training is a process of learning that includes the acquisition of knowledge, upgrading of skills, understanding the rules, or altering the attitude or behaviour to improve employees' performance (Sabir, Akhtar, Bukhari, Nasir and Ahmed, 2014). Elnaga and Imran (2013) referred training to the programs that aim to provide employees with necessary information and new skills that can increase their professional development opportunities.

With the rapid increase in competition, developing the knowledge and skills of an organization's employees have recently become very important to drive long-term performance, building competitive advantage, and ensuring continuous development (Singh and Mohanty, 2012). Sabir et al. (2014) indicated that training can be categorized into on-the-job or off-the-job training. The authors highlighted that on-the-job training takes place at the workplace using the available instruments, documents, equipment, or materials that the trainees need during the training program. In fact, on-the-job training has a universal repute as it is highly effective especially in occupational work. On the other hand, off-the-job training takes place outside the work place where employees do not count as directly productive workers. The advantage of off-the-job training appears in allowing employees to get away from their works for a while and focus more carefully on the training itself. In comparison with the on-job-training, this type of training has been confirmed to be more effective in enhancing employees' learning.

Training is regarded as an important variable for increasing organizational productivity. A number of scholars (Colombo and Stanca, 2008; Sepúlveda, 2010) thought about training as a primary and powerful tool to successfully accomplish organizational goals and objectives and enhancing employee productivity. According to April (2010), training programs are designed to provide greater benefits for the employee and the organization itself through increasing employees' performance using the shared knowledge, skills, and competencies. Sabir et al. (2014) found that training could enable employees to maximize their levels of productivity. That is, an employee will become more efficient and productive if he receives effective training (Elnaga and Imran, 2013). Asava (2014) also found that training has positive effect on employee productivity. Based on the above discussion, the following hypothesis is presented:

H3: Employee training has positive effect on employee productivity.

\section{Methodology}

The main purpose of this study is to test the effects of employee empowerment, teamwork, and employee training on employee productivity in Malaysian higher education sector. The population includes administrative and academic staff at public universities in northern Malaysia. This study adopts the quantitative approach where a survey method was utilized to collect the relevant data from respondents. Based on the recommendations of Krejcie and Morgan (1970) for determining sample size, a total of 242 questionnaires were considered acceptable for the sample size based on the population of the present study. By adopting a survey method, it would be possible to examine the link between the variables. The collected 
data was analysed using SPSS and structural equation modelling on AMOS.

In designing the questionnaire, the measurement items of constructs were taken from previous studies. For instance, five items were adapted from Chen and Tjosvold (2008); Lee and Brand (2010) to build the scale of employee productivity. To measure employee empowerment, seven items were adapted from Men (2010), because they had an acceptable reliability. Furthermore, five items were adapted from the study of Shanahan, Best, Finch, and Sutton (2007) to measure teamwork. Last but not least, a seven items scale was used to measure employee training. The items were taken from Schmidt (2004). The selected scales were reported at acceptable values of Cronbach's alpha reliability. All of the items were measured on a five-point Likert scale that ranges from 1 "strongly disagree" to 5 "strongly agree". The final questionnaire which comprises all items and questions related to respondents' profile was sent to three academicians from the same field to give their valuable suggestions to improve it and make sure that the respondents can understand all of the questions.

\section{Analysis of Results}

Out of 870 questionnaires being administered to the respondents, only 242 were returned. The results of demographic profile revealed that 65 (26.9\%) of the respondents are male, whereas $177(73.1 \%)$ are female. On age profile, $7 \%$ of those respondents were between 18 and 26 years old, while 121 (50\%) belong to the age category of 26 to 35 years. Those whose ages ranged between 36 and 45 years accounted for $40.5 \%$ of total response, but $16(6.6 \%)$ were in the age group of 46 years or above. In terms of academic qualification, the findings showed that $36(14.9 \%)$ had diploma degree, 79 (32.6\%) are holders of undergraduate degree, $125(51.7 \%)$ hold postgraduate degree, and $2(0.8 \%)$ had other certificates. Most of those respondents had more than five years of work experience in their institutions.

To examine the reliability of constructs, Cronbach's alpha was used. The results showed that the values of Cronbach's alpha for all constructs were satisfactory ranging from 0.771 to 925 ; employee productivity (0.755), employee empowerment (0.771), teamwork (0.925), and employee training (0.864). From these results, it is evident that the Cronbach's alpha reliability of all constructs is higher than the minimum required value of 0.70 as recommended by Pallant (2007). Furthermore, composite reliability was used to confirm the reliability assumptions on constructs. This procedure was done using Microsoft Excel. The findings also showed that the reliability values for all constructs are reasonable. Hence, the reliability of constructs is achieved.

To confirm construct validity, confirmatory factor analysis (CFA) was conducted. The main rationale of CFA is to fulfil the assumptions that each group of items which are supposed to measure a certain variable are really measuring it. Another objective of CFA is to provide additional support for convergent validity assumptions and solve any Multicollinearity issues. As all of the measurement items were adapted from previous studies, CFA rather than exploratory factor analysis (EFA) is used. Overall, CFA was conducted using structural equation modelling on AMOS 18 by drawing the measurement model which includes all items. In general, the results showed that the factor loading values of all items met the 
recommended criterion based on the suggestions of Hair el al. (2010). For more details, see Appendix A.

After ensuring that the data is free of Multicollinerity and the factor loadings of all items are acceptable, the structural model was then drawn with some model fit criterion to ensure that it fits the data well. As it can be seen in the below Figure, the structural model adequately fit the data, where the value of Chi-square is equal to 459.093. To support the Chi-square, other fit indices $(\mathrm{df}=183, \mathrm{GFI}=0.844$, AGFI $=0.803$, TLI $=0.879, \mathrm{CFI}=0.894$, and RMSEA $=$ 0.079) were used. Overall, the results point out that the model fit the data well as all the fit indices achieved the recommended cut-off values based on the suggestions of Hair et al. (2010).

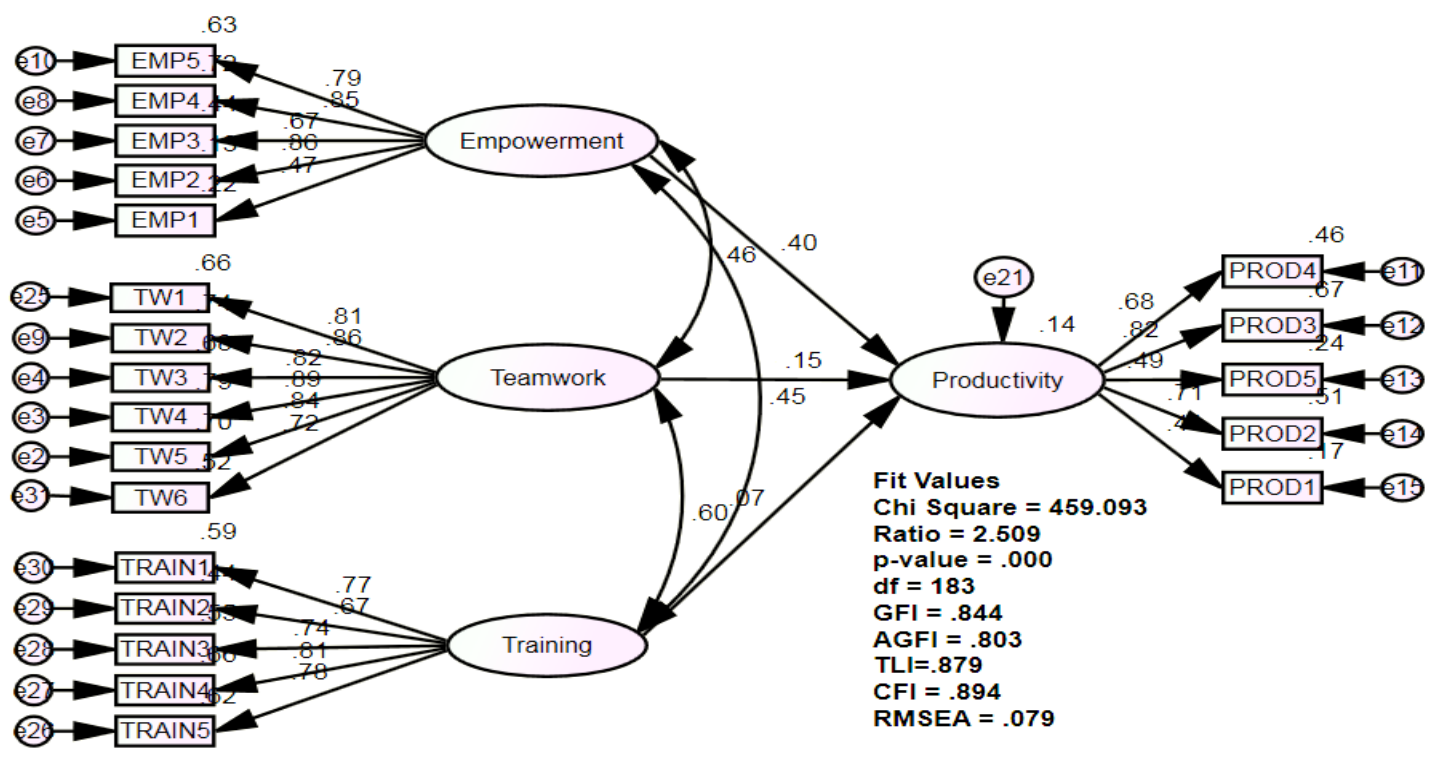

Figure 1. Structural Model

In order to test the hypotheses of this study, the regression table was taken from the output of structural model. The findings as shown in Table 1 reveal that employee empowerment has a significant positive effect on employee productivity $(\beta=0.402$, $\mathrm{t}$-value $=3.778, \mathrm{p}<0.05)$, therefore, $\mathrm{H} 1$ is accepted. The findings also revealed that teamwork has significant positive effect on employee productivity $(\beta=0.154$, $\mathrm{t}$-value $=3.577, \mathrm{p}<0.05)$, hence, $\mathrm{H} 2$ is accepted. Finally, the results also indicated that employee training has significant positive effect on employee productivity $(\beta=0.066$, $\mathrm{t}$-value $=2.841, \mathrm{p}<0.05)$, consequently, $\mathrm{H} 3$ is confirmed. Overall, employee empowerment, teamwork, and employee training explain 14 percent of total variance in employee productivity.

Table 1. Results of Hypotheses

Hypothesized Effect
Std.

Estimate
S.E. C.R. P Support

H1: Employee empowerment has $0.402 \quad 0.163 \quad 3.778 * * * \quad$ Yes positive effect on employee 
productivity.

H2: Teamwork has positive effect on $0.154 \quad 0.057 \quad 3.577$ *** $\quad$ Yes employee productivity.

H3: Employee training has positive $0.066 \quad 0.063 \quad 2.841 * * * \quad$ Yes effect on employee productivity.

\section{Discussion and Conclusion}

The rationale of this study was to examine the effects of human resource factors namely employee empowerment, teamwork, and employee training on employee productivity. To fulfil this objective, a number of employees at public universities in northern Malaysia were surveyed. The findings indicated that employee empowerment has significant positive effect on employee productivity. Greater support was noted in previous studies which found that employee empowerment was one of the main contributing factors to employee productivity and performance (Dobbs, 1993; Meyerson and Dewettinck, 2012). According to Karim and Rehman (2012), empowerment as a key management practice should be considered by managers for the sake of improving overall organizational performance. Moreover, Sahoo et al. (2010) confirmed that empowered employees make greater contributions for the organization and they are less likely to leave. These results indicate that employee empowerment is one of the significant factors for enhancing employee productivity and it should be given greater emphasis to reinforce overall organizational effectiveness.

The findings of this paper also showed that teamwork has a significant positive effect on employee productivity and this is in line with previous research (Lawler, Mohrman and Ledford, 1992). Past literature reported that ineffective teamwork can lead to unexpected outcomes such as decline in productivity and employee become unable to complete their tasks efficiently and on time (Salas, Sims, and Burke, 2005). Further, Khuong and Tien (2013) reported that effective teamwork had positive effect on employees' motivation, self-efficacy, and performance. Thus, building teamwork groups can significantly affect productivity growth, particularly, in spheres that necessitate creative problem solving skills, a high level of adaptability, and operational management (Kyzlinková, Dokulilová and Kroupa, 2007). The significance of teamwork in positively affecting employee productivity suggests that teamwork activities should be conducted and evaluated regularly in order to increase organizational performance through capitalizing on the knowledge and skills of employees and by inspiring them to accomplish the tasks as desired.

Finally, this study found that employee training has significant positive effect on employee productivity and it was supported by previous researches (Bhat, 2013; Hanif and Abdullah, 2013; Sultana et al., 2012; Vasudevan, 2014). The purpose of training is to improve the skills, knowledge, behaviour, and competencies of employees and ultimately to increase their performance and productivity. April (2010) stated that in order to maintain organizational 
performance, it is necessary to conduct training programs that can influence employees to be more creative. In other words, training is a key element for improving organizational performance and increasing employees' competences. This means that training will help employees to master their knowledge, skills, behaviour, and confidence in a manner that they feel able to perform efficiently and have positive effect on organizational performance. Therefore, this study concludes that by the adoption of training programs, employees become proficient in their jobs and able to give better results.

There are some limitations in this study that could be addressed in future researches. First, the sample was focused only on employees working in education sector. Therefore, it may not be generalizable to other industry contexts without further investigation. Moreover, only northern region of Malaysia was considered in this study; hence, it is suggested for future researches to cover larger areas. Additionally, this study examined the direct link between the independent and dependent variables. Future research may include moderating variables such as education level, age, and size of the organization. Finally, the quantitative approach was used for data collection. It is believed that by following the qualitative methodology, it will be possible to identify other key aspects that should be considered for designing effective human resource strategies in order to enhance employee productivity and organizational competitiveness.

\section{References}

Alie, R. E., Beam, H. H., \& Carey, T. A. (1998). The use of teams in an undergraduate management program. Journal of Management Education, 22(6), 707-719.

April, B. A. (2010). The impact of training on employee performance: A Case Study of HFC Bank (GHANA) Ltd. (Bachelor Thesis, Ashesi University College).

Asava, M. M. (2014). Influence of training on employee productivity in the processing sector: a case of unga limited eldoret, Kenya (Doctoral dissertation, University of Nairobi).

Benrazavi, S. R., \& Silong, A. D. (2013). Employees' job satisfaction and its influence on willingness to work in teams. Journal of Management Policy and Practice, 14(1), 127-140.

Betcherman, G. (1992). Are Canadian firms under investing in training? Canadian Business Economics, 1(1), 25-33.

Bhat, Z. H. (2013). Impact of training on employee performance: A Study of retail banking sector in India. Indian Journal of Applied Research, 3(6), 292-293.

Brown, M. (2008). Assessment methods in recruitment, selection and performance: A manager's guide to psychometric testing, interviews and assessment centres. Library Review, $57(2), 158-160$.

Chen, Y., \& Tjosvold, D. (2008). Collectivist values for productive teamwork between Korean and Chinese employees. Working Paper Series, Centre for Asian Pacific Studies. $\begin{array}{lllll}\text { Accessed on } & 19 & \text { June, } & & \end{array}$ http://commons.In.edu.hk/cgi/viewcontent.cgi?article=1002\&context=capswp 
Chukwudi, D. (2014). The impact of teamwork on organizational productivity. Retrieved on 6 October, 2014 from: http://nairaproject.com/projects/522.html

Cohen, S. G., \& Bailey, D. E. (1997). What makes teams work: Group effectiveness research from the shop floor to the executive suite. Journal of Management, 23(3), 239-290.

Colombo, E., \& Stanca, L. (2008). The impact of training on productivity: evidence from a large panel of firms. Accessed on 9 October, 2015 from: https://boa.unimib.it/retrieve/handle/10281/23176/29753/The_Impact_of_Training_on_Produ ctivity.pdf

Diab, S. M., \& Ajlouni, M. T. (2015). The influence of training on employee's performance, organizational commitment, and quality of medical services at Jordanian Private Hospitals. International Journal of Business and Management, 10(2), 117-127.

Dobbs, J. H. (1993). The empowerment environment. Training \& Development, 47(2), 55-57.

Elnaga, A., \& Imran, A. (2013). The effect of training on employee performance. European Journal of Business and Management, 5(4), 137-147.

Gallie, D., Zhou, Y., Felstead, A., \& Green, F. (2009). Teamwork, productive potential and employee welfare. SKOPE Research Paper, (84), 1-28.

Hameed, A., \& Amjad, S. (2009). Impact of office design on employees productivity: a case study of banking organizations of Abbottabad, Pakistan. Journal of Public Affairs, Administration and Management, 3(1), 1-13.

Hanif, F., \& Abdullah, A. (2013). Impact of training on employee's development and performance in hotel industry of Lahore, Pakistan. Journal of Business Studies Quarterly, 4(4), 68-82.

Ferreira, A., \& Du Plessis, T. (2009). Effect of online social networking on employee productivity. South African Journal of Information Management, 11(1), 1-11.

Hair, J. F., Black, W. C., Babin, B. J., Anderson, R. E., \& Tatham, R. L. (2006). Multivariate data analysis (Vol. 6). Upper Saddle River, NJ: Pearson Prentice Hall.

Hunjra, A. I., UlHaq, N., Akbar, S. W., \& Yousaf, M. (2011). Impact of employee empowerment on job satisfaction: an empirical analysis of Pakistani service industry. Interdisciplinary Journal of Contemporary Research in Business, 2(11), 680-685.

Jacquiline, F. N. (2014). Employee empowerment and job satisfaction. Researchjournali's Journal of Human Resource, 2(2), 1-12.

Jiang, X. (2010). How to motivate people working in teams. International Journal of business and Management, 5(10), 223.

Jones, A., Richard, B., Paul, D., Sloane, K., \& Peter, F. (2007). Effectiveness of team building in organization. Journal of Management, 5(3), 35-37.

Käpylä, J., Jääskeläinen, A., \& Lönnqvist, A. (2010). Identifying future challenges for 
productivity research: evidence from Finland. International Journal of Productivity and Performance Management, 59(7), 607-623.

Karim, F., \& Rehman, O. (2012).Impact of job satisfaction, perceived organizational justice and employee empowerment on organizational commitment in semi-government organizations of Pakistan. Journal of Business Studies Quarterly, 3(4), 92-104.

Kawara, P. (2014). Effects of reward systems on employee productivity in catholic university of eastern Africa. International Journal of Recent Research in Commerce Economics and Management, 1(2), 1-4.

Khuong, M. N., \& Tien, B. D. (2013). Factors influencing employee loyalty directly and indirectly through job satisfaction-A study of banking sector in Ho Chi Minh City. International Journal of Current Research and Academic Review, 1(4), 81-95.

Kien, B. T. (2012). Factors affecting the fluctuation of labour productivity in the construction projects. (Master Thesis, University of Economics), Ho Chi Minh City, Vietnam.

Kyzlinková, R., Dokulilová, L., \& Kroupa, A. (2007). Teamwork and high performance work organisation. Dublin, European Foundation for the Improvement of Living and Working Conditions.

Lawler, E. E., Mohrman, S. A., \& Ledford, G. E. (1992). Employee involvement and total quality management: Practices and results in Fortune 1000 companies. Jossey-Bass Inc.

Lee, S. Y., \& Brand, J. L. (2010). Can personal control over the physical environment ease distractions in office workplaces? Ergonomics, 53(3), 324-335.

Manzoor, S. R., Ullah, H., Hussain, M., \& Ahmad, Z. M. (2011). Effect of teamwork on employee performance. International Journal of Learning and Development, 1(1), 110-126.

Mathis, R. L. \& Jackson, J. H. (2000). Human resource management. Ohio: South Western Collage Publishing.

Mbinya, M. E. (2013). Factors affecting teamwork in export processing zones in Kenya: a case of Indigo Garments Export Procesing Zone LTD (Master's dissertation, Kenyatta University).

Men, L. R. (2010). Measuring the impact of leadership style and employee empowerment on perceived organizational reputation. Retrieved on 23 June, 2015 from: http://www.instituteforpr.org/wp-content/uploads/KEPRRA-the-Impact-of-Leadership-Styleand-Employee-Empowerment-on-Perceived-Organizational-Reputation.pdf

Meyerson, G., \& Dewettinck, B. (2012). Effect of empowerment on employees performance. Advanced Research in Economic and Management Sciences, 2, 40-46.

Michac, J. (1997). Stress and productivity. Trexima: Slovak Republic.

Mokhtar, A., Nooreha, H., Nik Mustapha, N. H., \& Mazilan, M. (2003). Value-based total performance excellence model: Baseline assessment criteria guidelines for organisations. 
Institute Islamic Understanding Malaysia, linebreak Kuala Lumpur.

Ooko, P. A. (2013). Impact of teamwork on the achievement of targets in organisations in Kenya.A case of SOS children's villages, Eldoret (Doctoral dissertation, University of Nairobi).

Oso, W. Y. (2002). State control and the management of public universities in Uganda, the case of Makerere University (Unpublished Master's thesis, Makerere University, Kampala).

Pallant, J. (2007). SPSS survival manual: A step-by-step guide to data analysis using SPSS version 15. Maidenhead, Berkshire, England: McGraw-Hill Education.

Ripley, R. E., \& Ripley, M. J. (1992). Empowerment, the cornerstone of quality: Empowering management in innovative organizations in the 1990s. Management Decision, 30(4), 20-43.

Sabir, R. I., Akhtar, N., Bukhari, F. A. S., Nasir, J., \& Ahmed, W. (2014). Impact of training on productivity of employees: A Case study of electricity supply company in Pakistan. International Review of Management and Business Research, 3(2), 595-606.

Sahoo, C. K., Behera, N., \&Tripathy, S. K. (2010). Employee empowerment and individual commitment: an analysis from integrative review of research. Employment Relations Record, 10(1), 40-56.

Saifullah, N., Alam, M., Zafar, M. W., \& Humayon, A. A. (2015). Job satisfaction: A Contest between human and organizational behavior. International Journal of Economic Research, $6(1), 45-51$.

Salas, E., Rosen, M. A., \& King, H. (2007). Managing teams managing crises: principles of teamwork to improve patient safety in the emergency room and beyond. Theoretical Issues in Ergonomics Science, 8(5), 381-394.

Schmidt, S. W. (2004). The job training and job satisfaction survey technical manual (East Carolina University). Online Submission. http://files.eric.ed.gov/fulltext/ED494451.pdf

Sepúlveda, F. (2010). Training and productivity: evidence for US manufacturing industries. Oxford Economic Papers, 62(3), 504-528.

Shanahan, C., Best, C., Finch, M., \& Sutton, C. (2007). Measurement of the behavioural, cognitive, and motivational factors underlying team performance. Defence Science and Technology Organisation Edinburgh (Australia) Air Operations Div.

Singh, R., \& Mohanty, M. (2012). Impact of training practices on employee productivity: A comparative study. Inter-science Management Review (IMR), 2, 2231-1513.

Sultana, A., Irum, S., Ahmed, K., \& Mehmood, M. (2012). Impact of training on employee performance: A Study of telecommunication sector in Pakistan. Interdisciplinary Journal of Contemporary Research in Business, 4(6), 646-661.

Vasudevan, H. (2014). Examining the relationship of training on job satisfaction and organizational effectiveness. International Journal of Management and Business Research, 
4(3), 185-202.

Vrat, P., Sardana, G. D., \& Sahay, B. S. (2009). Productivity measurement for business excellence. Alpha Science International.

\section{Appendix A: Measurement Scale of Final Item}

\begin{tabular}{|c|c|c|}
\hline Code & Construct/ Item & $\begin{array}{l}\text { Factor } \\
\text { Loading }\end{array}$ \\
\hline & Employee Empowerment $($ Cronbach's Alpha $=0.771)$ & \\
\hline EMP1 & I feel competent to perform the tasks required for my position; & 0.47 \\
\hline EMP2 & I am confident about my capabilities and skills to do my job. & 0.86 \\
\hline EMP3 & $\begin{array}{l}\text { I have the authority to make the necessary decisions to perform my } \\
\text { job well. }\end{array}$ & 0.67 \\
\hline EMP4 & $\begin{array}{l}\text { My manager trusts me to make the appropriate decisions in my } \\
\text { job. }\end{array}$ & 0.85 \\
\hline \multirow[t]{2}{*}{ EMP5 } & $\begin{array}{l}\text { I have considerable opportunity for interdependence and freedom } \\
\text { in how I do my job. }\end{array}$ & 0.79 \\
\hline & Teamwork (Cronbach's Alpha = 0.925) & \\
\hline TW1 & $\begin{array}{l}\text { The team members in my department help each other to get the } \\
\text { work done. }\end{array}$ & 0.81 \\
\hline TW2 & The members in my team feel very close to each other. & 0.86 \\
\hline TW3 & The members of my team really respect each another. & 0.82 \\
\hline TW4 & The members of my team work well together. & 0.89 \\
\hline TW5 & $\begin{array}{l}\text { The members of my team encourage each other to succeed when } \\
\text { performing the task. }\end{array}$ & 0.84 \\
\hline \multirow[t]{2}{*}{ TW6 } & The members of my team work hard to get things done. & 0.72 \\
\hline & Employee Training $($ Cronbach's Alpha $=\mathbf{0 . 8 6 4})$ & \\
\hline
\end{tabular}




\begin{tabular}{|c|c|c|}
\hline TRAIN1 & $\begin{array}{l}\text { My department provides learning/training opportunities to meet } \\
\text { the changing needs of the workplace }\end{array}$ & 0.77 \\
\hline TRAIN2 & $\begin{array}{l}\text { Training and development are encouraged and rewarded in my } \\
\text { department. }\end{array}$ & 0.67 \\
\hline TRAIN3 & Overall, the on-the-job training I receive is applicable to my job. & 0.74 \\
\hline TRAIN4 & Overall, the training I receive on the job meets my needs. & 0.81 \\
\hline TRAIN5 & $\begin{array}{l}\text { Overall, I am satisfied with the amount of training I receive on the } \\
\text { job. }\end{array}$ & 0.78 \\
\hline & Employee Productivity (Cronbach's Alpha = 0.755) & \\
\hline PROD1 & I do large amount of work each day & 0.48 \\
\hline PROD2 & I accomplish tasks quickly and efficiently. & 0.71 \\
\hline PROD3 & I have a high standard of task accomplishment. & 0.82 \\
\hline PROD4 & My work outcomes are of high quality. & 0.68 \\
\hline PROD5 & I always beat our team targets. & 0.49 \\
\hline
\end{tabular}

